\title{
Waterborne and Airborne Microfibers Shed from Non-Woven Materials in Water and Air Environments
}

\author{
Soojin Kwon \\ North Carolina State University \\ Marielis C. Zambrano \\ North Carolina State University \\ Richard A. Venditti \\ North Carolina State University \\ Ryen Frazier \\ North Carolina State University \\ Franklin Zambrano \\ North Carolina State University \\ Ronalds W. Gonzalez \\ North Carolina State University \\ Joel Justin Pawlak ( $\nabla_{\text {jjpawlak@ncsu.edu ) }}$ \\ North Carolina State University https://orcid.org/0000-0002-9803-9004
}

\section{Research Article}

Keywords: Microfiber, Nonwovens, Aquatic environment, Air environment, Dusting, Meltblown nonwovens

Posted Date: December 13th, 2021

DOl: https://doi.org/10.21203/rs.3.rs-996055/v1

License: (c) (i) This work is licensed under a Creative Commons Attribution 4.0 International License. Read Full License 


\section{Abstract}

Nonwoven products are widely used in various fields, including many disposable products, such as wipes, diapers, and masks. However, microfibers shed from these products in the aquatic and air environment have not been fully described. In the present study, several commercial single-use nonwoven products and a series of meltblown nonwoven materials produced in a pilot plant were investigated regarding their microfiber generation during their use in aquatic and air environments. Microfibers shed in water were studied using a Launder Ometer equipment (1- $65 \mathrm{mg}$ of microfibers per gram material), and microfibers shed in air were evaluated using a dusting testing machine that shakes a piece of the nonwoven back and forth ( 0 to 6000 microfibers ( 4 mg of microfibers) per gram material). The raw materials and bonding technologies applied to the commercial nonwovens affected the microfiber generation both in water and air conditions. Meltblown nonwoven fabrics generated fewer microfibers compared to the other commercial nonwovens studied here, and the manufacturing factors, such as DCD (Die to collector distance) and air flow rate, affected the tendency of microfiber generation. Microfibers of nonwovens shed in water and air environment were compared to selected textile materials and paper tissue materials. The results herein suggest that it is possible to control the tendency of microfiber shedding through the choice of operating parameters during nonwoven manufacturing processes.

\section{Introduction}

Plastics have been used in many fields with their efficient processibility and formability and exceptional performance. However, by their resistance to biodegradation, the plastic wastes have accumulated persistently. From 1950 to 2015, 6,300 million metric tons of plastic waste had been generated, and only $21 \%$ of wastes had been managed by recycling or incinerating (Geyer et al. 2017). Further, 4.8 to 12.7 million metric tons of plastic wastes were discharged from coastal regions to the ocean in 2010 worldwide (Jambeck et al. 2015), and it was estimated that over 250,000 tons of plastic particles are floating in the ocean globally (Eriksen et al. 2014), which have threatened marine life (Lusher et al. 2015). As well as macro-sized plastics, microplastics of which diameters are less than $5 \mathrm{~mm}$ (Boucher and Friot 2017) have also been a growing issue, especially with regards to their ingestible size (Setälä 2014; Lusher et al. 2015). Microplastics were reported to occupy over $13 \mathrm{wt} \%$ of plastic particles floating on the sea surface globally (Eriksen et al. 2014).

Among microplastics, microfibers are the most dominant form of microplastics (Dubaish and Liebezeit 2013), and they are commonly $50 \mu \mathrm{m}$ to a few $\mathrm{mm}$ in length and less than $10 \mu \mathrm{m}$ in diameter (Kane and Clare 2019). With their ingestible sizes, it has been reported that marine organisms, including fish and deep-sea organisms, ingest microfibers (Lusher et al. 2015; Rochman et al. 2015; Taylor et al. 2016). Considering that humans are at the very top of the food chain, it is inevitable for humans to ingest the microfibers from food. Microfibers also exist in the air, especially indoor air (Dris et al. 2017), and it has been reported that both natural and synthetic fibers were present in human lungs in 99 of 114 human lung specimens (Pauly et al. 1998).

Microfibers are known to mainly originate from textiles and are often composed of synthetic polymers, most notably polyester, which are resistant to degradation (Browne et al. 2011; Dubaish and Liebezeit 2013; Zambrano et al. 2019, 2020, 2021a). However, there are still many other sources of generating microfibers, including nonwovens. Nonwovens are used in various fields in various forms and the use of them has been a rising issue as they sometimes are discarded improperly and might be a source of shed microfibers. With the emergence of COVID-19, the production and demands of the nonwoven mask have increased tremendously, and the risk of generation and inhaling of microplastics from wearing masks have also been described (Hasan et al. 2020; Aragaw 2020; Fadare and Okoffo 2020; Li et al. 2021).

Nonwovens are ubiquitous materials in our lives as their product performance/properties can be tuned depending on raw materials and production processes. For instance, nonwovens are used as raw materials for personal care products, such as wet wipes, and surgical gown masks and gowns, and also in geotextile products. The fiber morphology of the nonwoven materials vary depending on their production process and final purpose; for example, from micron dimension to nano dimension in fiber diameters, which are fatal to the human respiratory system: the particle-sized below $2.5 \mu \mathrm{m}$ can be inhaled and penetrate the lung and even the bloodstream (US EPA 2016; World Health Organization 2018). Also considering that particles below $3 \mu \mathrm{m}$ diameter can penetrate the outermost layer of the epidermis (stratum corneum) (De Spiegeleer et al. 2011; Bolzinger et al. 2011), the possibility of microfiber from nonwoven products, such as personal care or hygiene products, or face masks, penetrating the human skin cannot be overlooked. 
Even though the nonwoven products are the possible source of microfibers, only a limited amount of research has been done on microfiber generation from nonwovens (Martínez Silva and Nanny 2020; Ó Briain et al. 2020; Aragaw 2020; Fadare and Okoffo 2020; Li et al. 2021). Some of the studies have pointed out the potential microfiber generation from nonwoven products, such as face masks (Hasan et al. 2020; Aragaw 2020; Fadare and Okoffo 2020; Li et al. 2021). However, most studies on nonwoven microfiber generation have been focused on the analysis of microfibers in river sediments (Martínez Silva and Nanny 2020; Ó Briain et al. 2020). One study by Li et al. (2021) investigated the microfiber generation during the use of face masks using a vacuum pump to simulate microfiber generation by inhaling. However, microfibers can be generated by many different situations, for example, by shaking or mechanical impacts. There is a need to simulate the microfiber generation with other mechanical actions.

Global nonwoven consumption is estimated to grow from 11.2 million tons, valued at $\$ 46.8$ billion in 2019 to $\$ 64.8$ billion by 2024 (Smithers Pira 2017; Nonwovens industry 2019). With the increased production of nonwoven disposables, the effect of nonwoven products on our environment has been inevitably increased. Also around two-third of the nonwoven products are made of synthetic materials (EDANA 2019). Therefore, the environmental effect of nonwoven products, especially on microfiber generation, needs to be clarified. The present study, therefore, investigates aquatic and air-borne microfiber generation of nonwovens with several types of nonwoven materials: a set of commercial nonwoven wet wipes and a series of meltblown nonwoven fabrics produced under controlled pilot plant conditions.

Nonwoven wet wipes are one of the most highly produced nonwoven products along with hygiene products (EDANA 2017), and wet wipes are exposed to several mechanical actions during their use, such as abrasion, shaking, and mechanical impact. Also, they are made of different raw materials with different manufacturing processes depending on their final purpose. It is of interest to understand how the materials and manufacturing impact microfiber generation/shedding. Further, many wet wipes are discarded into the sewage systems, causing significant problems (Mitchell et al. 2017). Therefore their behavior in the aquatic condition is important to understand their impacts on microfibers in the aquatic environment. Meltblown nonwovens are nonwoven fabrics widely used for face masks. In this study, microfiber shedding of meltblown nonwovens was investigated with a series of materials produced with different manufacturing conditions. This study is expected to provide basic information on the propensity of nonwoven materials to shed microfibers. The present research is critical information to be considered by manufacturers and decision-makers when they develop, purchase, and use nonwovens.

\section{Materials And Methods}

Materials

A total of fifteen commercial non-woven products (listed in Table 2) that reflect the major types of disposable wet wipes were collected and have been physically and chemically characterized. A variety of products were collected to represent the diversity of products and to develop the relationships between the physical and chemical properties and micro-particle generation.

The nonwoven wet wipes collected in this study are commercial products in which the manufacturing processes could not be completely known nor systematically controlled. Therefore, sixteen kinds of polypropylene nonwoven meltblown fabrics were produced in a pilot plant environment and investigated to further determine relationships between web structures and microfiber generation. The manufacturing process included the following steps and equipment. The meltblown fabrics were produced with a Refirenhauser Reicofil R4 Meltblown Pilot Line in the Nonwoven Institute at North Carolina State University. The melted polypropylene polymer was extruded through small nozzles in the meltblown die with high-temperature and high-speed air flow. The filaments of polypropylene were collected on the collector and could be consolidated without any bonding technologies. The meltblown structure and properties were altered by the rate of the high-temperature air and the distance between the die and the collector (DCD). Key manufacturing parameters of the meltblown nonwovens are shown in Table 1. 
Table 1

Manufacturing conditions of meltbown nonwovens

\begin{tabular}{|lllll|}
\hline Samples & Basis Weight $\left(\mathbf{g} / \mathbf{m}^{2}\right)$ & DCD $(\mathbf{m m})$ & $\begin{array}{l}\text { Air } \\
\left(\mathbf{m}^{3} / \mathbf{h} / \mathbf{m} \text { die width }\right)\end{array}$ & $\begin{array}{l}\text { Throughput } \\
(\mathbf{k g} / \mathbf{h r} / \mathbf{m})\end{array}$ \\
\hline MB1 & 10 & 150 & 350 & 15.5 \\
\hline MB2 & 25 & 150 & 350 & 15.5 \\
\hline MB3 & 25 & 150 & 650 & 15.5 \\
\hline MB4 & 25 & 200 & 650 & 15.5 \\
\hline MB5 & 25 & 250 & 650 & 15.5 \\
\hline MB6 & 25 & 250 & 850 & 15.5 \\
\hline MB7 & 25 & 200 & 850 & 15.5 \\
\hline MB8 & 25 & 150 & 850 & 15.5 \\
\hline MB9 & 25 & 200 & 350 & 15.5 \\
\hline MB10 & 25 & 250 & 350 & 15.5 \\
\hline MB11 & 50 & 250 & 350 & 15.5 \\
\hline MB12 & 25 & 150 & 1000 & 46.7 \\
\hline MB13 & 25 & 250 & 1000 & 46.7 \\
\hline MB14 & 25 & 250 & 1425 & 77.9 \\
\hline MB15 & 25 & 150 & 1425 & 77.9 \\
\hline MB16 & 300 & 350 & 500 & 73.0 \\
\hline
\end{tabular}

Characterization of commercial products and meltblown nonwovens

Nonwoven commercial products were characterized with several techniques to clarify their raw materials, web structures, and manufacturing technologies used for the products, such as web formation and bonding. Nonwoven commercial products were thermally analyzed with Thermal Gravimetric Analysis (TGA, TGA Q500, TA instruments, DE, USA) and Differential Scanning Calorimetry (DSC, DSC Q2000, TA instruments, DE, USA), to specify the raw materials with their decomposition and melting temperatures. Also, Fourier transform Infrared Spectroscopy (FT-IR Spectrometer Frontier with Universal ATR Sampling Accessory, ParkinElmer Inc., USA) was used to analyze the materials composing the nonwoven commercial products.

Optical microscopic images and scanning electron microscopic (SEM) images of nonwoven materials were taken to characterize web structure and raw materials by a Nikon Eclipse E200 (Tokyo, Japan) and JCM-6000Plus Versatile Benchtop SEM (JEOL, Japan): fiber width of meltblown nonwovens was analyzed with the SEM images and Image J program (National Institutes of Health, USA), and web bonding structures of commercial products were identified by the microscopic images. For characterizing the raw materials in the products, the nonwoven products were stained with Textile Identification DuPont Stain\#4 (Test Fabrics, Inc., PA, USA) before taking microscopic images. Both stained and unstained nonwoven products were analyzed.

The basis weight of meltblown nonwovens was measured after conditioning the nonwovens in the constant temperature and humidity $\left(23^{\circ} \mathrm{C}, 50 \%\right.$ humidity) (ASTM $\left.3776 / 3776 \mathrm{M}, 2020\right)$. The thickness was measured by $49-56$ Micrometer (Messmer Büchel, Metherlands) in the same condition of the basis weight measurement. Fabric density was calculated with the basis weight and thickness of nonwoven materials.

Other physical properties of nonwoven surfaces, such as softness, roughness, and stiffness, were investigated with a Textile Softness Analyzer (TSA, Emtec, Germany). The TSA measures the softness and roughness by analyzing the sounds generated 
from the rotation of blades on the surface. It also measures the stiffness, plasticity, elasticity, and hysteresis by deformation of the materials.

Waterborne microfiber generation

Experiments were conducted in order to determine the propensity of the material to shed fibers or particles under mechanical actions in aquatic conditions, following methodology described in previous research for fabrics (Zambrano et al. 2019). As shown in Fig. 1, Micro-particle generation of commercial wet wipes was investigated using a Launder-Ometer (SDL Atlas, LLC, SC, USA), which is most often used for testing fabric dye fastness. Twenty-five metal balls, which had $6 \mathrm{~mm}$ of diameter, were added into the container with $150 \mathrm{~mL}$ of deionized water with the test specimen. The temperature of the water was $22^{\circ} \mathrm{C}$. The size of the test specimen was $102 \times 102 \mathrm{~mm}^{2}\left(4 \times 4 \mathrm{in}^{2}\right)$ cut with a paper guillotine-type trimmer and was not hemmed on the edges. One sheet of test specimens was inserted into each canister. After running the Launder-Ometer, the water with the shed microfibers was collected by passing through a thick wire mesh screen (opening size of $1 \times 1 \mathrm{~mm}^{2}$ ) that retained the nonwoven material and the metal balls. The suspension was then filtered using glass microfiber filters (Grade GF/A, Whatman plc, UK), and the weight of the solids that were retained on the filter paper was measured. The fiber morphology and the number of microfibers were analyzed with a Fiber Quality analyzer (FQA, OpTest Equipment Inc., Canada). FQA analyzes fiber quality, including length, width, and curl with circular polarized light and a single camera. Fibers with the length of $0.05 \mathrm{~mm}$ to $10 \mathrm{~mm}$ were measured in the present research.

Airborne microfiber generation

The microfiber generation from shedding in an air environment was simulated with the Tissue Dust Analyzer (TDA, Fig. 2). Four sheets of nonwoven materials of dimensions $102 \mathrm{~mm}$ by $102 \mathrm{~mm}$ ( 4 in by 4 in) were attached by clip onto two metal arms (two sheets for each metal arm) which were connected to a motor. The rotation speed of the motor was set as $120 \mathrm{spm}$ (strokes per minute), and the test specimens were swung back and forth (total distance of $60 \mathrm{~mm}$ ) for four minutes. The microfibers generated accumulated within the testing chamber of the TDA and were collected by spraying deionized water into the chamber to rinse all of the shed microfibers. The number of microfibers was counted by the FQA with the same condition of the waterborne microfiber condition.

\section{Results \& Discussion}

Characteristics of nonwoven commercial products and meltblown nonwovens

Commercial nonwoven product compositions were estimated based on various analysis methods: TGA, DSC, and FT-IR. The details are included in the supplementary materials. The melting temperature and decomposition characteristics can be used to characterize the types of materials in the non-woven. The melting temperature can be compared to known standards for common polymers used in non-woven. The thermal decomposition measured by TGA can be used to evaluate materials that do not have a melting temperature, ex. cellulose. FT-IR spectra (Fig. S1-S3) can be used as further confirmation of the composition. SEM and optical microscope were also used to characterize the morphology of the fibers. (Fig. S4-S11). Specially, cellulosic fibers, including natural cellulosic fiber and regenerated cellulosic fiber, could be distinguished by their shape in the microscopic images; ribbon shape of the natural fibers (including wood pulp fibers and cotton fibers), and the round shape of the regenerated fibers. Table 3 shows the results of this analysis.

The majority of the non-woven materials were composed of more than one type of fiber. Cellulosic fibers were found to be a common material used in the products. In all cases, cellulose is also combined with a synthetic polymer. This may be attributed to the ability of the synthetic material to provide wet strength to the wipes. Among synthetic fibers, polyester and polypropylene fibers were most commonly found. There are only two commercial products were made of a single synthetic material: 11 and I2. Both products are industrial wipe products, which may be more focused on the nonwoven strength.

More than half of the products were determined to be made by carding and hydroentangling or thermal bonding. Since the products are wet wipes, the manufacturing process seemed to be focused on the water absorbency and softness. These properties are important product properties for wet wipes. The cellulosic fiber is hydrophilic with many hydroxyl groups in its structure. 
Page 6/23 
Table 2

Characteristics of nonwoven commercial products (P: Personal care products, $\mathrm{H}$ : Household products, I: Industrial products, HC: Healthcare products; PE: Polyethylene, PP: Polypropylene, PET: polyester terephthalate; values in parentheses are standard deviation (SD) values). *open product information

\begin{tabular}{|c|c|c|c|c|c|c|c|c|}
\hline Samples & $\begin{array}{l}\text { Raw } \\
\text { materials }\end{array}$ & $\begin{array}{l}\text { Basis } \\
\text { weight } \\
\left(\mathrm{g} / \mathrm{m}^{2}\right)\end{array}$ & $\begin{array}{l}\text { Fabric } \\
\text { density } \\
\left(\mathrm{g} / \mathrm{cm}^{3}\right)\end{array}$ & $\begin{array}{l}\text { Fiber } \\
\text { width } \\
(\mu \mathrm{m})\end{array}$ & $\begin{array}{l}\text { Melting } \\
\text { Temperature } \\
\left({ }^{\circ} \mathrm{C}\right)\end{array}$ & $\begin{array}{l}\text { \# of } \\
\text { decompositions } \\
\text { in TGA }\end{array}$ & $\begin{array}{l}\text { Web } \\
\text { formation }\end{array}$ & Bonding \\
\hline P1 & $\begin{array}{l}\text { Wood pulp*, } \\
\text { regenerated } \\
\text { cellulose*, } \\
\text { PE }\end{array}$ & $\begin{array}{l}72.4 \\
( \pm 1.6)\end{array}$ & 0.14 & $\begin{array}{l}14.4 \\
( \pm 2.5)\end{array}$ & $\mathrm{N} / \mathrm{A}$ & 3 & Wet laid & $\begin{array}{l}\text { Hydroentangling } \\
\text { \& chemical } \\
\text { binder }\end{array}$ \\
\hline P2 & $\begin{array}{l}\text { Wood pulp*, } \\
\text { regenerated } \\
\text { cellulose* }\end{array}$ & $\begin{array}{l}51.7 \\
( \pm 1.1)\end{array}$ & 0.11 & $\begin{array}{l}29.0 \\
( \pm 8.8) \\
10.9 \\
( \pm 0.6)\end{array}$ & $\mathrm{N} / \mathrm{A}$ & 1 & Carded & Hydroentangling \\
\hline P3 & $\begin{array}{l}\text { Wood pulp*, } \\
\text { PP* }\end{array}$ & $\begin{array}{l}51.5 \\
( \pm 1.1)\end{array}$ & 0.08 & $\begin{array}{l}33.0 \\
( \pm 7.9) \\
3.7 \\
( \pm 1.3)\end{array}$ & 152 & 2 & $\begin{array}{l}\text { Wood pulp } \\
\& \\
\text { meltblown } \\
\text { (CoForm*) }\end{array}$ & $\begin{array}{l}\text { Thermal } \\
\text { bonding }\end{array}$ \\
\hline P4 & $\begin{array}{l}\text { PP, natural } \\
\text { cellulose }\end{array}$ & $\begin{array}{l}54.3 \\
( \pm 1.2)\end{array}$ & 0.09 & $\begin{array}{l}29.1 \\
( \pm 5.3) \\
3.3 \\
( \pm 2.0)\end{array}$ & 147 & 2 & CoForm & $\begin{array}{l}\text { Thermal } \\
\text { bonding }\end{array}$ \\
\hline P5 & $\begin{array}{l}\mathrm{PE}, \\
\text { regenerated } \\
\text { cellulose }\end{array}$ & $\begin{array}{l}42.0 \\
( \pm 0.8)\end{array}$ & 0.08 & $\begin{array}{l}15.0 \\
( \pm 2.4)\end{array}$ & 244 & 2 & Carded & Hydroentangling \\
\hline P6 & $\begin{array}{l}\text { Regenerated } \\
\text { cellulose } \\
\text { (Viscose }^{\star} \text { ) }\end{array}$ & $\begin{array}{l}42.6 \\
( \pm 1.6)\end{array}$ & 0.13 & $\begin{array}{l}12.4 \\
( \pm 1.3)\end{array}$ & $\mathrm{N} / \mathrm{A}$ & 1 & Carded & $\begin{array}{l}\text { Hydroentangled } \\
\text { \& chemical } \\
\text { binder }\end{array}$ \\
\hline \multirow[t]{2}{*}{ P7 } & & $\begin{array}{l}51.2 \\
( \pm 0.6)\end{array}$ & 0.11 & $\begin{array}{l}14.3 \\
( \pm 2.4)\end{array}$ & 249 & 3 & Carded & Hydroentangling \\
\hline & $\begin{array}{l}\text { Regenerated } \\
\text { cellulose }\end{array}$ & & & & & & & \\
\hline $\mathrm{H} 1$ & $\begin{array}{l}\text { PP, natural } \\
\text { cellulose }\end{array}$ & $\begin{array}{l}46.6 \\
( \pm 1.4)\end{array}$ & 0.08 & $\begin{array}{l}17.1 \\
( \pm 1.3) \\
29.3 \\
( \pm 9.5)\end{array}$ & 160 & 2 & $\begin{array}{l}\text { Spunbond- } \\
\text { wood } \\
\text { pulp- } \\
\text { spunbond }\end{array}$ & $\begin{array}{l}\text { Hydroentangling } \\
\text { \& thermal } \\
\text { bonding }\end{array}$ \\
\hline $\mathrm{H} 2$ & $\begin{array}{l}\text { PP, natural } \\
\text { cellulose, } \mathrm{PE}\end{array}$ & $\begin{array}{l}56.2 \\
( \pm 1.3)\end{array}$ & 0.12 & $\begin{array}{l}36.3 \\
( \pm 8.2) \\
14.8 \\
( \pm 3.8)\end{array}$ & 159,245 & 2 & $\begin{array}{l}\text { Carded, } \\
\text { spunbond } \\
\& \\
\text { meltblown }\end{array}$ & $\begin{array}{l}\text { Thermal } \\
\text { bonding }\end{array}$ \\
\hline H3 & $\begin{array}{l}\mathrm{PE}, \mathrm{PP}, \\
\text { natural } \\
\text { cellulose }\end{array}$ & $\begin{array}{l}56.0 \\
( \pm 0.8)\end{array}$ & 0.15 & $\begin{array}{l}33.6 \\
( \pm 7.8) \\
16.9 \\
( \pm 0.8)\end{array}$ & 138 & 2 & Carded & $\begin{array}{l}\text { Hydroentangling } \\
\text { \& thermal } \\
\text { bonding }\end{array}$ \\
\hline $\mathrm{H} 4$ & $\begin{array}{l}\text { PP, natural } \\
\text { cellulose }\end{array}$ & $\begin{array}{l}59.5 \\
( \pm 1.0)\end{array}$ & 0.15 & $\begin{array}{l}30.4 \\
( \pm 7.5) \\
17.8 \\
( \pm 0.6)\end{array}$ & 152 & 2 & Carded & $\begin{array}{l}\text { Hydroentangling } \\
\text { \&thermal } \\
\text { bonding }\end{array}$ \\
\hline I1 & PP* & $\begin{array}{l}33.0 \\
( \pm 0.3)\end{array}$ & 0.12 & $\begin{array}{l}3.6 \\
( \pm 1.5)\end{array}$ & 153 & 1 & Meltblown & $\begin{array}{l}\text { Thermal } \\
\text { bonding }\end{array}$ \\
\hline 12 & $\mathrm{PE}^{\star}$ & $\begin{array}{l}53.5 \\
( \pm 2.4)\end{array}$ & 0.11 & $\begin{array}{l}13.8 \\
( \pm 0.9)\end{array}$ & 254 & 1 & Carded & Hydroentangling \\
\hline $\mathrm{HC} 1$ & $\begin{array}{l}\text { PP*, natural } \\
\text { cellulose }\end{array}$ & $\begin{array}{l}33.9 \\
( \pm 1.3)\end{array}$ & 0.10 & $\begin{array}{l}33.6 \\
( \pm 7.8) \\
15.3 \\
( \pm 0.8)\end{array}$ & 164 & 2 & $\begin{array}{l}\text { Spunbond- } \\
\text { wood } \\
\text { pulp- } \\
\text { spunbond }\end{array}$ & $\begin{array}{l}\text { Hydroentangling } \\
\text { \& thermal } \\
\text { bonding }\end{array}$ \\
\hline
\end{tabular}




\begin{tabular}{|lllllllll|}
\hline Samples & $\begin{array}{l}\text { Raw } \\
\text { materials }\end{array}$ & $\begin{array}{l}\text { Basis } \\
\text { weight } \\
\left(\mathbf{g} / \mathbf{m}^{2}\right)\end{array}$ & $\begin{array}{l}\text { Fabric } \\
\text { density } \\
\left(\mathbf{g} / \mathbf{c m}^{3}\right)\end{array}$ & $\begin{array}{l}\text { Fiber } \\
\text { width } \\
(\boldsymbol{\mu m})\end{array}$ & $\begin{array}{l}\text { Melting } \\
\text { Temperature } \\
\left({ }^{\circ} \mathrm{C}\right)\end{array}$ & $\begin{array}{l}\text { \# of } \\
\text { decompositions } \\
\text { in TGA }\end{array}$ & $\begin{array}{l}\text { Web } \\
\text { formation }\end{array}$ & Bonding \\
\hline HC2 & $\begin{array}{l}\text { Regenerated } \\
\text { cellulose*, }\end{array}$ & $\begin{array}{l}175 \\
( \pm 14.6)\end{array}$ & 0.09 & $\begin{array}{l}16.4 \\
( \pm 2.7)\end{array}$ & 116,242 & 2 & $\begin{array}{l}\text { Spunbond } \\
\text { \& Carded }\end{array}$ & $\begin{array}{l}\text { Needle-punched } \\
\text { \& chemical } \\
\text { binder }\end{array}$ \\
\hline
\end{tabular}

Table 3 shows the characteristics of the meltblown series of samples, including fiber width, basis weight, fabric density, and thickness. The fiber widths were determined using the optical microscopic images (Fig. S7). Compared to the nonwoven commercial products, meltblown nonwovens were composed of finer synthetic fibers.

Table 3

Characteristics of meltblown nonwoven

\begin{tabular}{|c|c|c|c|c|}
\hline Samples & Fiber width $(\mu \mathrm{m})$ & Basis weight $\left(\mathrm{g} / \mathrm{m}^{2}\right)$ & Fabric thickness $(\mu \mathrm{m})$ & Fabric density $\left(\mathrm{g} / \mathrm{cm}^{3}\right)$ \\
\hline MB1 & 3.52 & 11 & 259 & 0.042 \\
\hline MB2 & 3.61 & 26 & 388 & 0.067 \\
\hline MB3 & 2.41 & 27 & 298 & 0.090 \\
\hline MB4 & 2.20 & 25 & 300 & 0.083 \\
\hline MB5 & 2.85 & 26 & 333 & 0.077 \\
\hline MB6 & 2.51 & 27 & 413 & 0.066 \\
\hline MB7 & 2.54 & 27 & 362 & 0.076 \\
\hline MB8 & 2.73 & 26 & 314 & 0.082 \\
\hline MB9 & 3.07 & 24 & 388 & 0.063 \\
\hline MB10 & 3.45 & 26 & 395 & 0.066 \\
\hline MB11 & 3.60 & 50 & 538 & 0.093 \\
\hline MB12 & 3.08 & 24 & 305 & 0.078 \\
\hline MB13 & 3.87 & 24 & 293 & 0.083 \\
\hline MB14 & 2.96 & 24 & 287 & 0.085 \\
\hline MB15 & 3.12 & 24 & 263 & 0.091 \\
\hline MB16 & 5.62 & 330 & 1860 & 0.17 \\
\hline
\end{tabular}

The physical properties of nonwoven commercial products and meltblown nonwovens were analyzed with the Textile Softness Analyzer (TSA). The detailed results of TSA, including roughness, softness, and compliance of commercial products are illustrated in the supplementary information (Table S1-S3). The TSA was also used to characterize the softness and compliance of meltblown lab samples. The softness can correlate with the increased bulkiness of the sample amongst other factors. Fig. 3 shows the TSA results for the lab-made meltblown nonwovens. The TS7 value measured by the TSA is inversely related to the softness and the TS750 value is related to the roughness. Lower TS7 and TS750 values indicate improved softness and smoother surface. The TS7 and TS750 values correspond to the sound created by the fan blades of the instrument brushing across the sample. Also, a compliance value was measured that represents the deformation of the material when a $600 \mathrm{mN}$ load is applied. Higher values represent a more flexible material.

The physical properties of the meltblown nonwovens were more affected by the airflow rate compared to the DCD (Fig. 3). With the higher airflow rate, the meltblown nonwovens had softer and less rough surfaces with a higher compliance. This can be 
related to the fiber width changes caused by the airflow rate. It has been well known that the meltblown manufactured with higher airflow rate is composed of finer fibers, which is also confirmed in the present study (Fig. 4).

DCD also affected the physical properties of meltblown nonwovens, even though the effect of DCD was less pronounced than the effect of airflow rate. Also, when DCD was higher, the surface became softer and appeared to have less roughness. Also considering that the compliance values increased with the DCD, it seemed that meltblown nonwovens with higher DCD were more flexible materials. Even though the grammages of the nonwovens were the almost same, the thickness of the nonwovens increased with the increase of DCD (average 304 um (SD: $\pm 47 \mathrm{um}$ ) for DCD $150 \mathrm{~mm} ; 350$ um for DCD $200 \mathrm{~mm} ; 377$ um (SD: $\pm 45 \mathrm{um}$ ) for DCD $250 \mathrm{~mm}$ (SD: $\pm 94 \mathrm{um})$ ), and in turn, the density of the web decreases with the increase of DCD (Fig. 3 (d)).

Waterborne microfiber generation

The microfiber shed in a water environment from selected products was tested as a function of agitation time (Fig. 5) in the Launder Ometer. Samples P3, P6, and P7, which showed the lowest, moderate, and highest microfiber generation at sixteen minutes, were tested versus time. The P6 sample, which showed the lowest microfiber generation, did not show a significant difference in microfiber generation as a function of time. However, samples P3 and P7, which generated more microfibers at the sixteen minutes condition, showed a different behavior with time. The particle generation increased sharply at early times (before 5 minutes), and then plateaued. The results indicate that for some products microfibers may be generated with a relatively small amount of mechanical action which may be found in wastewater treatment plants during pumping as an example.

Table 4 shows the overall result of microfiber generation for commercial nonwoven products. Compared to the textile fabrics investigated under the same experimental conditions (Zambrano et al. 2019), more microfibers in general were generated from commercial nonwoven fabrics. According to Zambrano et al. (2019), generally less than $3 \mathrm{mg}$ of microfibers are generated per gram of fabric at room temperature with or without detergent present. However, in the present study, most of the commercial nonwovens generated over $10 \mathrm{mg}$ of microfibers per gram of wipes. The structural difference between the textile fabrics and the nonwoven fabrics are a probable cause of this difference. The textile fabrics in the previous study were made of yarns and they were interlocked by knitting. However, commercial nonwovens in the present study were bonded by different technologies, such as hydroentangling, thermal bonding, and needle-punching, and there might be more free fibers exposed to the surface without strong attachment to the material.

The amount of microfiber generated from the commercial nonwovens was different depending on the sample and their product categories. Personal care wipes and household wipes generally generated more micro-particles compared to the industrial and healthcare wet wipes.

The number of microfibers shed in water was further analyzed by FQA. The tendency of microfiber generation was shown to be relatively similar to the gravimetric results of microfiber generation (Table 4). Nevertheless, the P7 sample showed relatively small amounts of fibers even though it showed a very high weight of shed microfibers. This was caused by the lotion/detergent of commercial products being weighed on the filter paper, so this sample was excluded in the further comparisons. 
Table 4

Microfiber generation of nonwoven commercial products for sixteen minutes. (Values in parentheses are the standard deviation from three repeated measurements)

\begin{tabular}{|c|c|c|c|c|c|c|c|c|}
\hline \multirow{2}{*}{$\begin{array}{l}\text { Categories/ } \\
\text { Samples }\end{array}$} & & & \multicolumn{3}{|c|}{ Micro-particle (mg/g wipes) } & \multicolumn{3}{|l|}{ FQA } \\
\hline & & & $\begin{array}{l}\text { Each } \\
\text { sample }\end{array}$ & Average & SD & $\begin{array}{l}\text { The number of } \\
\text { microfibers }\end{array}$ & $\begin{array}{l}\text { Length of } \\
\text { microfiber }(\mathrm{mm})\end{array}$ & $\begin{array}{l}\text { Width of } \\
\text { microfiber }(\mu \mathrm{m})\end{array}$ \\
\hline \multirow{7}{*}{$\begin{array}{l}\text { Personal } \\
\text { Care }\end{array}$} & $\mathrm{P} 1$ & 44 & $( \pm 3)$ & \multirow[t]{7}{*}{26} & \multirow[t]{7}{*}{$( \pm 17)$} & 424,000 & 0.79 & 24.4 \\
\hline & P2 & 17 & $( \pm 1)$ & & & 584,000 & 0.71 & 22.8 \\
\hline & P3 & 36 & $( \pm 1)$ & & & 465,000 & 0.70 & 25.3 \\
\hline & P4 & 30 & $( \pm 1)$ & & & $1,130,000$ & 0.52 & 26.1 \\
\hline & P5 & 9 & $( \pm 2)$ & & & 18,000 & 0.77 & 18.8 \\
\hline & P6 & 1 & $( \pm 1)$ & & & 33,000 & 1.06 & 18.9 \\
\hline & P7 & 65 & $( \pm 15)$ & & & 23,000 & 1.03 & 18.4 \\
\hline \multirow[t]{4}{*}{ Household } & $\mathrm{H} 1$ & 16 & $( \pm 3)$ & \multirow[t]{4}{*}{27} & \multirow[t]{4}{*}{$( \pm 14)$} & 32,000 & 1.16 & 26.1 \\
\hline & $\mathrm{H} 2$ & 15 & $( \pm 2)$ & & & 331,000 & 0.57 & 26.4 \\
\hline & $\mathrm{H} 3$ & 33 & $( \pm 1)$ & & & 645,000 & 1.03 & 25.0 \\
\hline & $\mathrm{H} 4$ & 44 & $( \pm 11)$ & & & $1,150,000$ & 1.16 & 25.9 \\
\hline \multirow[t]{2}{*}{ Industrial } & 11 & 2 & $( \pm 2)$ & \multirow[t]{2}{*}{2} & \multirow[t]{2}{*}{$( \pm 0)$} & 11,900 & 0.80 & 20.1 \\
\hline & 12 & 2 & $( \pm 1)$ & & & 31,300 & 0.85 & 15.9 \\
\hline \multirow[t]{2}{*}{ Healthcare } & HC1 & 20 & $( \pm 4)$ & \multirow[t]{2}{*}{12} & \multirow[t]{2}{*}{$( \pm 2)$} & 170,000 & 0.99 & 25.1 \\
\hline & HC2 & 4 & $( \pm 1)$ & & & 44,700 & 1.02 & 20.5 \\
\hline
\end{tabular}

The microfiber generation result was further compared to their raw materials and web structures (Fig. 6). When examining the microfiber generation by fiber type (i.e. regenerated/natural cellulosic fibers, synthetic, or both), the majority of the samples were made of more than two kinds of fibers. The nonwoven products only with synthetic fibers or regenerated cellulosic fibers generated the lowest amount of microfibers, however, the nonwoven containing natural fibers generated relatively greater amounts of microfiber (Fig. 6 (a)). This result corresponds to the previous research that the textile fabrics made of synthetic fibers generated fewer microfibers than those with natural cotton fibers (Zambrano et al. 2019). It may be said that synthetic fibers or regenerated cellulosic fibers are more uniform compared to natural fibers, so they have less chance to be broken than natural fibers.

Six out of the fifteen commercial products were formed by carding technology, and even in the carding group, the amount of microfiber generation was very different between samples (Fig. 6 (b)). Commercial nonwovens formed by wetlaid, SPS, and CoForm showed a relatively higher amount of microfiber generation, and this was related to the raw materials of the commercial nonwovens; those three web forming technologies are usually used with natural cellulosic fibers, such as wood pulp fibers. In terms of bonding applied to the commercial nonwovens, thermal bonded nonwovens generated the most amount of microfibers (Fig. 6 (c)). In case of thermal bonded nonwovens in this research, most samples were bonded by point, stick, or grind bonding, and no area bonding was observed. Thus, even after the bonding, there should be non-bonded areas locally, and from those nonbounded areas, microfibers are expected to be shed. Also, hydroentangling seemed to make the nonwovens resistant to microfiber generation; hydroentangled nonwovens generated the least amount of microfibers.

As shown in the cellulosic fiber group and hydroentangling group, the materials investigated in the present experiment were randomly collected commercial products and the factors or characteristics of the materials were not well balanced across the spectrum of products. From the controlled manufactured nonwoven fabrics, it was also expected to better explore other 
characteristics of nonwoven structures, including basis weight, density, or thickness, affecting micro-particle generation. Also, most of the nonwovens in the commercial products were formed by carding, so the result could only represent the carded nonwovens, which is only a part of nonwoven variations. Further, recent interest has been focused on the microfiber generation of the facial mask with the occurrence of pandemic (COVID-19), and its material which is generally made of meltblown nonwovens. However, the microfiber generation of meltblown nonwovens has not been fully investigated. Therefore, further study was done to investigate the effects of different factors on micro-particle generation with known well-controlled meltblown nonwoven manufacturing process variables.

The meltblown nonwovens generated a microfiber weight from $0-2 \mathrm{mg} / \mathrm{g}$ of nonwoven in the LaunderOmeter experiments and a number of microfibers from 170 to 8750 count/g of nonwoven equipment (Table 5).

Table 5

Microfiber generation of meltblown nonwovens. Weight of microfiber was repeated three times and a single trial of FQA was done for each material.

\begin{tabular}{|c|c|c|c|c|c|}
\hline \multirow[t]{2}{*}{ Samples } & \multicolumn{2}{|c|}{$\begin{array}{l}\text { Weight of microfiber } \\
\text { (mg/g material) }\end{array}$} & \multicolumn{3}{|l|}{ FQA } \\
\hline & Average & SD & $\begin{array}{l}\text { The number of microfibers } \\
\text { (\#/g material) }\end{array}$ & Length of microfiber (mm) & Width of microfiber $(\mu \mathrm{m})$ \\
\hline MB1 & 1.26 & $( \pm 1.27)$ & 2860 & 0.58 & 19.0 \\
\hline MB2 & 0.52 & $( \pm 0.37)$ & 943 & 0.75 & 18.2 \\
\hline MB3 & 0.18 & $( \pm 0.51)$ & 2050 & 0.64 & 18.0 \\
\hline MB4 & 0.78 & $( \pm 0.82)$ & 5720 & 0.39 & 18.0 \\
\hline MB5 & 1.19 & $( \pm 0.22)$ & 3400 & 1.12 & 17.8 \\
\hline MB6 & 1.43 & $( \pm 2.57)$ & 2660 & 0.69 & 18.7 \\
\hline MB7 & 1.18 & $( \pm 2.35)$ & 2950 & 0.63 & 18.5 \\
\hline MB8 & 0.94 & $( \pm 0.80)$ & 8750 & 0.50 & 20.5 \\
\hline MB9 & 0.59 & $( \pm 1.35)$ & 1250 & 0.71 & 19.7 \\
\hline MB10 & 0.68 & $( \pm 0.81)$ & 2180 & 0.52 & 17.8 \\
\hline MB11 & 1.05 & $( \pm 0.39)$ & 640 & 0.71 & 18.0 \\
\hline MB12 & 0.47 & $( \pm 0.41)$ & 4770 & 0.59 & 19.6 \\
\hline MB13 & 1.32 & $( \pm 0.27)$ & 5020 & 0.74 & 17.9 \\
\hline MB14 & 0.02 & $( \pm 0.18)$ & 2740 & 0.65 & 20.2 \\
\hline MB15 & 0.00 & $( \pm 0.35)$ & 901 & 0.65 & 18.3 \\
\hline MB16 & 0.03 & $( \pm 0.03)$ & 171 & 0.63 & 20.2 \\
\hline
\end{tabular}

In melt spinning, it is known that longer die-to-collector distance (DCD) creates a bulkier sheet (Zhang et al. 2018). The airflow rate and polymer throughput are also closely related to the fiber morphology. Thus, the relationships between fiber and web properties and microfiber generation were investigated with the pilot plant meltblown materials relative to these known processing variables.

Figure 7 (a) shows that the number of microfibers generally increases as air flow rate increases. If the airflow rate increases, the fiber diameter decreases because the polymer is pushed by the air as shown in Figure 4 (statistically significant, $p<.005$ ). However, the number of microfibers and the fiber width did not show statistically significant relationships. In Figure 3 , the increased air flow rate increased the softness, decreased the roughness and increased the compliance of the meltblown nonwovens. Therefore, it may be said that the meltblown nonwovens had thinner fibers from the high airflow rate, which made the meltblown nonwoven 
vulnerable to microfiber generation; however, the microfiber generation of meltblown nonwovens cannot be explained only with the single factor such as fiber width, and other structural properties also combine to effect the microfiber generation.

Figure 7 (b) shows the microfiber generation depending on the DCD of meltblown nonwovens when the throughput of the polypropylene was $15.5 \mathrm{~kg} / \mathrm{hr} / \mathrm{m}$. When the DCD was at the higher value, $250 \mathrm{~mm}$, the maximum difference due to differences in air flow of the number of microfibers was 2760 per gram material; however, when DCD was $150 \mathrm{~mm}$, the difference was 7810 per gram material. That is, the effect of air flow rate on the microfiber generation was much greater when the meltblown was manufactured with the shorter DCD than the longer DCD.

No statistical impact on microfibers generated was observed versus basis weight for the set of experiments conducted.

Although nonwovens are generally not intended for home laundering (washing and drying), oftentimes these materials are inadvertently home laundered. It is of interest to estimate the microfibers shed during home laundering. Previous research in this group has shown in comparisons of the Launder Ometer and actual home wash laundering that the microfibers shed in home washing for a variety of fabrics is about 1/40th that of the Launder Ometer results (Zambrano et al. 2019). In general, the microfibers shed herein for nonwovens in a water environment using the Launder Ometer equipment resulted in a range of 0 $1,150,000$ number of microfibers or $1-65 \mathrm{mg}$ of microfibers generated per gram material. It is thus estimated that $0.025-6.6 \mathrm{mg}$ of microfibers would be shed during normal home wash laundering of the non-wovens based on the previous research results (Zambrano et al. 2019).

Airborne microfiber generation

It is known that for fabrics that microfibers are shed during normal use in air (Pauly et al. 1998; Dris et al. 2017), and thus it was deemed useful to evaluate nonwovens microfiber generation in air (dusting). Samples of nonwovens were shaken back and forth within a TDA and the generated fibers were collected and analyzed. Unlike waterborne microfibers, the weight of airborne microfiber generated could not be measured, the results were so low that weight measurements with our filtration method were unreliable. Thus, the number of microfibers was measured by FQA (Table 6). Similar to waterborne microfibers, airborne microfiber generated less from the nonwoven products made of synthetic fibers and/or regenerated cellulosic fibers (Fig. 8 (a)); however, the tendency was less distinct compared to the result of waterborne microfiber generation. The airborne microfiber showed a similar amount between different groups of web formation; however, the bonding technologies have a more significant influence on airborne microfiber generation (Fig. 8 (b) \& (c)). The nonwoven products only bonded by a single technology, especially nonwoven products only bonded by thermal, generally generated higher amounts of microfibers than those bonded with double-bonded technology (Hydroentangling and thermal bonding, others (hydroentangling or needle-punched with chemical binders)). 
Table 6

Microfiber generation of nonwoven commercial products by TDA for four minutes. The number of fibers was counted by FQA after the microfibers were collected by deionized water.

\begin{tabular}{|c|c|c|c|c|c|}
\hline \multirow{2}{*}{\multicolumn{2}{|c|}{$\begin{array}{l}\text { Categories/ } \\
\text { Samples }\end{array}$}} & \multicolumn{4}{|c|}{ Micro-particle (\#/g wipes) } \\
\hline & & \multicolumn{2}{|c|}{ Each sample } & \multicolumn{2}{|c|}{ Average } \\
\hline \multirow[t]{7}{*}{ Personal Care } & P1 & 315 & $( \pm 248)$ & 1790 & $( \pm 2210)$ \\
\hline & P2 & 4270 & $( \pm 722)$ & & \\
\hline & P3 & 5510 & $( \pm 3050)$ & & \\
\hline & P4 & 1130 & $( \pm 991)$ & & \\
\hline & P5 & 0 & $( \pm 37)$ & & \\
\hline & P6 & 14 & $( \pm 1300)$ & & \\
\hline & P7 & 1300 & $( \pm 683)$ & & \\
\hline \multirow[t]{4}{*}{ Household } & $\mathrm{H} 1$ & 0 & $( \pm 8)$ & 321 & $( \pm 373)$ \\
\hline & $\mathrm{H} 2$ & 695 & $( \pm 725)$ & & \\
\hline & H3 & 0 & $( \pm 785)$ & & \\
\hline & $\mathrm{H} 4$ & 588 & $( \pm 1990)$ & & \\
\hline \multirow[t]{2}{*}{ Industrial } & 11 & 339 & $( \pm 58)$ & 931 & $( \pm 836)$ \\
\hline & 12 & 1520 & $( \pm 1690)$ & & \\
\hline \multirow[t]{2}{*}{ Healthcare } & $\mathrm{HC} 1$ & 1300 & $( \pm 54)$ & 883 & $( \pm 590)$ \\
\hline & $\mathrm{HC} 2$ & 465 & $( \pm 1570)$ & & \\
\hline
\end{tabular}

The same experiment was done with the meltblown nonwovens (Table 7); however, the average number of microfibers was much lower (525 microfibers per gram material) compared to the commercial nonwoven products (1,160 microfibers per gram material). Also, half of the meltblown nonwovens showed statistically zero microfibers per gram material (lower or the same microfiber values relative to the control condition in which the TDA was run without a sample). Therefore it may be said that the meltblown nonwovens generate a significantly lower amount of microfibers in the air environment than the commercial products in general. 
Table 7

Microfiber generation of meltblown nonwovens by TDA.

\begin{tabular}{|lll|}
\hline & \multicolumn{2}{l|}{ Microfibers } \\
& $(\# / g$ material) \\
\cline { 2 - 3 } & Average & SD \\
\hline MB1 & 5760 & $( \pm 6640)$ \\
\hline MB2 & 849 & $( \pm 816)$ \\
\hline MB3 & 255 & $( \pm 108)$ \\
\hline MB4 & 291 & $( \pm 72)$ \\
\hline MB5 & 0 & $( \pm 223)$ \\
\hline MB6 & 0 & $( \pm 277)$ \\
\hline MB7 & 0 & $( \pm 197)$ \\
\hline MB8 & 0 & $( \pm 479)$ \\
\hline MB9 & 811 & $( \pm 989)$ \\
\hline MB10 & 327 & $( \pm 371)$ \\
\hline MB11 & 35 & $( \pm 149)$ \\
\hline MB12 & 71 & $( \pm 47)$ \\
\hline MB13 & 0 & $( \pm 117)$ \\
\hline MB14 & 0 & $( \pm 171)$ \\
\hline MB15 & 0 & $( \pm 99)$ \\
\hline MB16 & 0 & $( \pm 36)$ \\
\hline
\end{tabular}

Even though lower numbers of microfibers were generated with meltblown nonwovens, we could find that the microfiber generation of meltblown decreased with the increase of basis weight (Fig. 9). This might be related to the fabric density. When a meltblown is manufactured the fibers from the die are collected on the collector. So, when the basis weight increases, more fibers are collected on top of the previously collected fabrics. For this series of samples, the density was determined to be higher with the higher basis weight (Fig. 9). The fibers in the denser meltblown nonwovens might be interlocked more with each other compared to the fibers in the less dense meltblown nonwovens. Thus, there might be more stress applied to fibers at low basis weight/low density during the dusting experiment.

Comparison of microfiber generation in water and air condition with other materials

Microfibers from commercial nonwovens in the water condition were much higher than microfibers from the textile fabric cotton and polyester materials, whereas the meltblown nonwovens generated a similar amount of microfibers as the textile fabrics (Table 8). Commercial nonwovens containing natural cellulosic materials generated significant amounts of microfibers due to relatively irregular fiber morphologies and the weak properties of cellulosic fibers, especially in the water environment. However, considering the previous result that showed the rapid aquatic biodegradation of microfibers from the cotton and rayon textile materials (Zambrano et al. 2019, 2020, 2021b), it is expected that the environmental effects of the cellulosic components of the commercial nonwovens are not significant even though the number shed is higher than synthetics that persist and do not biodegrade in the environment. The tissue paper completely disintegrated in the water, releasing all of the fibers into the water, as expected. 
Microfiber generation of nonwoven materials in the air environment, including commercial and meltblown nonwovens, are compared with textile and tissue paper materials (Table 8). In the air environment, the microfiber generation of commercial and meltblown nonwovens was comparable to those of textile materials, including cotton and polyester textile materials, but much lower than the microfibers from the tissue paper materials. Cotton textile fabrics generated more microfibers than the synthetic polyester fabrics in air; similarly, the commercial nonwovens composed in part of natural cellulosic fibers generated comparably more microfibers than nonwovens composed of synthetic or regenerated cellulosic fibers in air.

Table 8

Microfiber generation of nonwoven, textile, and tissue paper materials in water air conditions. (Commercial: commercial nonwoven products) (a: (Zambrano et al. 2019); b: calculated based on the coarseness of fibers with the assumption that all fibers are disintegrated, c: assumed that all fibers are disintegrated, d: Ryen Frazier (2021), NCSU, unpublished data, e: calculated based on the density of the materials; for commercial and meltblown nonwovens, the values are the averaged value of all materials tested in the present research, and for the textile and tissue materials, the values are the averaged values from the three repeated experiments; the values in parentheses are the standard deviation.)

\begin{tabular}{|c|c|c|c|c|c|}
\hline \multicolumn{2}{|l|}{ Materials } & \multirow{2}{*}{$\begin{array}{l}\text { Microfibers in water } \\
\text { condition } \\
\text { (\#/g material) } \\
548,000( \pm 385,000)\end{array}$} & \multirow{2}{*}{$\begin{array}{l}\text { Microfibers in water } \\
\text { condition } \\
\text { (mg/g material) } \\
28( \pm 12)\end{array}$} & \multirow{2}{*}{$\begin{array}{l}\text { Microfibers in air } \\
\text { condition } \\
\text { (\#/g material) } \\
1530( \pm 1980)\end{array}$} & \multirow{2}{*}{$\begin{array}{l}\text { Microfibers in air } \\
\text { condition }{ }^{\mathrm{e}} \\
\text { (mg/g material) } \\
0.91( \pm 1.19)\end{array}$} \\
\hline \multirow[t]{5}{*}{ Nonwoven } & Commercial & & & & \\
\hline & $\begin{array}{l}\text { with natural } \\
\text { fibers }\end{array}$ & & & & \\
\hline & Commercial & $27,800( \pm 12,800)$ & $3.6( \pm 3.2)$ & $606( \pm 652)$ & $0.26( \pm 0.25)$ \\
\hline & $\begin{array}{l}\text { without natural } \\
\text { fibers }\end{array}$ & & & & \\
\hline & $\begin{array}{l}\text { Meltblown (PP } \\
\text { fibers) }\end{array}$ & $2,940( \pm 2,230)$ & $0.73( \pm 0.49)$ & $525( \pm 1,420)$ & $0.20( \pm 0.53)$ \\
\hline \multirow[t]{2}{*}{ Textile } & Cotton & $6,320( \pm 1,920)^{a}$ & $0.25( \pm 0.26)^{a}$ & $1,180( \pm 160)$ & $0.58( \pm 0.16)$ \\
\hline & Polyester & $1,520( \pm 230)^{a}$ & $0.15( \pm 0.07)^{a}$ & $470( \pm 1)$ & $0.13( \pm 0.01)$ \\
\hline \multirow[t]{2}{*}{ Tissue } & $\begin{array}{l}\text { Tissue1 (natural } \\
\text { fibers) }\end{array}$ & $6,750,000^{b}$ & $1,000^{c}$ & $10,900( \pm 960)^{d}$ & $3.2( \pm 0.3)$ \\
\hline & $\begin{array}{l}\text { Tissue2 (natural } \\
\text { fibers) }\end{array}$ & $3,400,000^{b}$ & $1,000^{c}$ & $14,400( \pm 540)^{d}$ & $4.0( \pm 0.2)$ \\
\hline
\end{tabular}

\section{Conclusions}

Microfiber generation of nonwoven materials was investigated by simulating the mechanical action applied to the materials in two different conditions: water and air conditions. Fifteen commercial nonwoven products and sixteen kinds of polypropylene labmade meltblown nonwovens were tested in the present research. The waterborne microfibers were generated in the largest amounts from the personal care and household nonwoven products. When hydroentangling was applied and when the nonwovens contained less natural cellulosic fibers, less microfibers were generated. The structure and physical properties of pilot plant meltblown nonwovens were different depending on their manufacturing factors (DCD and air flow rate), ultimately affecting the microfiber generation. Higher DCD and airflow rate contributed to making bulkier and softer meltblown nonwovens with higher compliance. In particular, higher airflow rate produced a finer fiber width that significantly affected the physical properties of meltblown nonwoven and generated more microfibers in the water condition.

Airborne microfiber generation showed a similar tendency with the waterborne microfiber generation for the commercial nonwovens, however, the difference between the materials was less distinct compared to the waterborne microfiber generation. Nevertheless, in the air environment the commercial nonwovens made of natural fibers generated relatively more microfibers. The doubly bonded nonwovens generated significantly less amount of microfibers. Meltblown nonwovens generated significantly 
lower amounts of microfibers during the dusting condition than the water environment; nevertheless, the number of microfibers decreased in the meltblowns with higher basis weight and density.

Commercial nonwovens generated much higher amounts of microfibers shed in the water environment compared to some selected textile materials and much lower amounts of microfibers relative to select paper tissue materials that fully disintegrated in the water environment.

Meltblown polypropylene nonwovens showed similar microfiber shedding as polyester fabrics in water and air environments.

Overall, this study defines the range of microfiber generation for commercial nonwovens and lab-made meltblown nonwovens in water and airborne conditions. The study can be useful for material selection and manufacturing variables in order to reduce microfiber generation from nonwovens.

\section{Declarations}

\section{Ethics approval and consent to participate}

Not applicable

\section{Consent for publication}

Not applicable

\section{Availability of data and materials}

All data generated or analysed during this study are included in this published article and its supplementary information files.

\section{Competing interests}

The authors declare that they have no competing of interests.

\section{Funding}

This study was funded by the Nonwoven Institute (NWI) at NC State University.

\section{Authors' contributions}

All authors contributed to the study conception and design. Material preparation, data collection and analysis were performed by Soojin Kwon, Marielis C. Zambrano, Richard A. Venditti, Ryan Fraizer, Franklin Zambrano, Ronalds W. Gonzalez, and Joel J. Pawlak. The first draft of the manuscript was written by Soojin Kwon and all authors commented on previous versions of the manuscript. All authors read and approved the final manuscript.

\section{Acknowledgements}

This research was supported by the Nonwoven Institute (NWI) at NC State University. Their support is gratefully acknowledged.

\section{Funding}

Conflicts of interest/Competing interests 
The authors declare that they have no conflict of interest.

Availability of data and material

not applicable

Code availability

not applicable

\section{References}

1. Aragaw TA (2020) Surgical face masks as a potential source for microplastic pollution in the COVID-19 scenario. Mar Pollut Bull 159:111517. https://doi.org/10.1016/j.marpolbul.2020.111517

2. Bolzinger M, Briançon S, Chevalier Y (2011) Nanoparticles through the skin: managing conflicting results of inorganic and organic particles in cosmetics and pharmaceutics. Wiley Interdiscip Rev Nanomed Nanobiotechnol 3:463-478. https://doi.org/10.1002/wnan.146

3. Boucher J, Friot D (2017) Primary microplastics in the oceans: A global evaluation of sources. IUCN International Union for Conservation of Nature

4. Browne MA, Crump P, Niven SJ, et al (2011) Accumulation of Microplastic on Shorelines Woldwide: Sources and Sinks. Environ Sci 5. https://doi.org/10.1021/es201811s

5. De Spiegeleer B, Boonen J, Baert B, et al (2011) Skin penetration of silica microparticles. Pharmazie 463-464. https://doi.org/10.1691/ph.2011.0854

6. Dris R, Gasperi J, Mirande C, et al (2017) A first overview of textile fibers, including microplastics, in indoor and outdoor environments. Environ Pollut 221:453-458. https://doi.org/10.1016/j.envpol.2016.12.013

7. Dubaish F, Liebezeit G (2013) Suspended Microplastics and Black Carbon Particles in the Jade System, Southern North Sea. Water Air Soil Pollut 8. https://doi.org/10.1007/s11270-012-1352-9

8. EDANA (2019) Sustainability Report 2019

9. EDANA (2017) Nonwoven statistics 2017 (data 2016). 2017:3

10. Eriksen M, Lebreton LCM, Carson HS, et al (2014) Plastic Pollution in the World's Oceans: More than 5 Trillion Plastic Pieces Weighing over 250,000 Tons Afloat at Sea. PLoS ONE 9:1-15. https://doi.org/10.1371/journal.pone.0111913

11. Fadare 00, Okoffo ED (2020) Covid-19 face masks: A potential source of microplastic fibers in the environment. Sci Total Environ 737:140279. https://doi.org/10.1016/j.scitotenv.2020.140279

12. Geyer R, Jambeck JR, Law KL (2017) Production, use, and fate of all plastics ever made. Sci Adv 3:e1700782. https://doi.org/10.1126/sciadv.1700782

13. Hasan NA, Bashar A, Heal RD, Haque MM (2020) Face Masks - Protecting the Wearer But Neglecting the Aquatic Environment? SSRN Electron J. https://doi.org/10.2139/ssrn.3722737

14. Jambeck JR, Geyer R, Wilcox C, et al (2015) Plastic waste inputs from land into the ocean. Science 347:768-771. https://doi.org/10.1126/science.1260352

15. Kane IA, Clare MA (2019) Dispersion, Accumulation, and the Ultimate Fate of Microplastics in Deep-Marine Environments: A Review and Future Directions. Front Earth Sci 7:80. https://doi.org/10.3389/feart.2019.00080

16. Li L, Zhao X, Li Z, Song K (2021) COVID-19: Performance study of microplastic inhalation risk posed by wearing masks. J Hazard Mater 411:124955. https://doi.org/10.1016/j.jhazmat.2020.124955

17. Lusher AL, Hernandez-Milian G, O'Brien J, et al (2015) Microplastic and macroplastic ingestion by a deep diving, oceanic cetacean: The True's beaked whale Mesoplodon mirus. Environ Pollut 199:185-191.

https://doi.org/10.1016/j.envpol.2015.01.023

18. Martínez Silva P, Nanny MA (2020) Impact of Microplastic Fibers from the Degradation of Nonwoven Synthetic Textiles to the Magdalena River Water Column and River Sediments by the City of Neiva, Huila (Colombia). Water 12:1210. 
https://doi.org/10.3390/w12041210

19. Mitchell RL, Thamsen PU, Gunkel M, Waschnewski J (2017) Investigations into wastewater composition focusing on nonwoven wet wipes. Tech Trans 10:125-135. https://doi.org/10.4467/2353737XCT.17.010.61

20. Nonwovens industry (2019) Smithers Pira Releases Global Nonwovens Report. Nonwovens Ind.

21. Ó Briain O, Marques Mendes AR, McCarron S, et al (2020) The role of wet wipes and sanitary towels as a source of white microplastic fibres in the marine environment. Water Res 182:116021. https://doi.org/10.1016/j.watres.2020.116021

22. Pauly L, Stegmeier J, Cheney T, et al (1998) Inhaled Cellulosic and Plastic Fibers Found in Human Lung Tissue. Cancer Epidemiol Biomarkers Prev 7:419-428

23. Rochman CM, Tahir A, Williams SL, et al (2015) Anthropogenic debris in seafood: Plastic debris and fibers from textiles in fish and bivalves sold for human consumption. Sci Rep 5:14340. https://doi.org/10.1038/srep14340

24. Setälä $O$ (2014) Ingestion and transfer of microplastics in the planktonic food web. Environ Pollut 7. https://doi.org/10.1016/j.envpol.2013.10.013

25. Smithers Pira (2017) The Future of Global Nonwovens to 2022

26. Taylor ML, Gwinnett C, Robinson LF, Woodall LC (2016) Plastic microfibre ingestion by deep-sea organisms. Sci Rep 6:33997. https://doi.org/10.1038/srep33997

27. US EPA O (2016) Particulate Matter (PM) Basics. In: US EPA. https://www.epa.gov/pm-pollution/particulate-matter-pm-basics. Accessed 25 Feb 2021

28. World Health Organization (2018) Air pollution and child health: prescribing clean air

29. Zambrano MC, Pawlak JJ, Daystar J, et al (2019) Microfibers generated from the laundering of cotton, rayon and polyester based fabrics and their aquatic biodegradation. Mar Pollut Bull 142:394-407.

https://doi.org/10.1016/j.marpolbul.2019.02.062

30. Zambrano MC, Pawlak JJ, Daystar J, et al (2020) Aerobic biodegradation in freshwater and marine environments of textile microfibers generated in clothes laundering: Effects of cellulose and polyester-based microfibers on the microbiome. Mar Pollut Bull 151:110826. https://doi.org/10.1016/j.marpolbul.2019.110826

31. Zambrano MC, Pawlak JJ, Daystar J, et al (2021a) Impact of dyes and finishes on the microfibers released on the laundering of cotton knitted fabrics. Environ Pollut 272:115998. https://doi.org/10.1016/j.envpol.2020.115998

32. Zambrano MC, Pawlak JJ, Daystar J, et al (2021b) Impact of dyes and finishes on the aquatic biodegradability of cotton textile fibers and microfibers released on laundering clothes: Correlations between enzyme adsorption and activity and biodegradation rates. Mar Pollut Bull 165:112030. https://doi.org/10.1016/j.marpolbul.2021.112030

33. Zhang H, Liu J, Zhang X, et al (2018) Design of electret polypropylene melt blown air filtration material containing nucleating agent for effective PM2.5 capture. RSC Adv 8:7932-7941. https://doi.org/10.1039/C7RA10916D

\section{Figures}



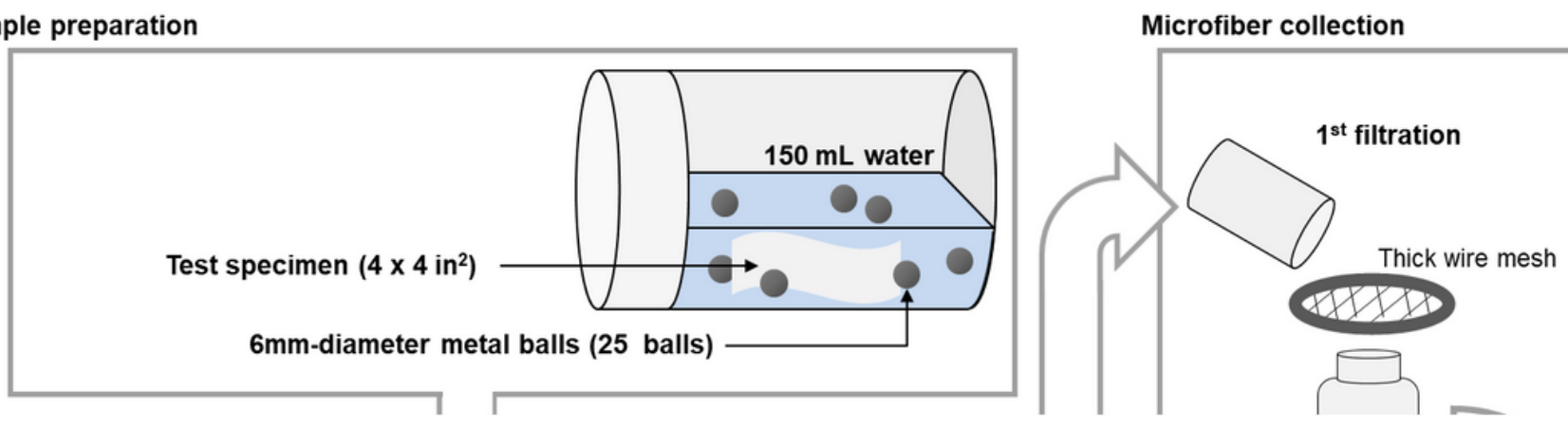

Figure 1

Schematic of the waterborne microfiber generation process

Acrylic box

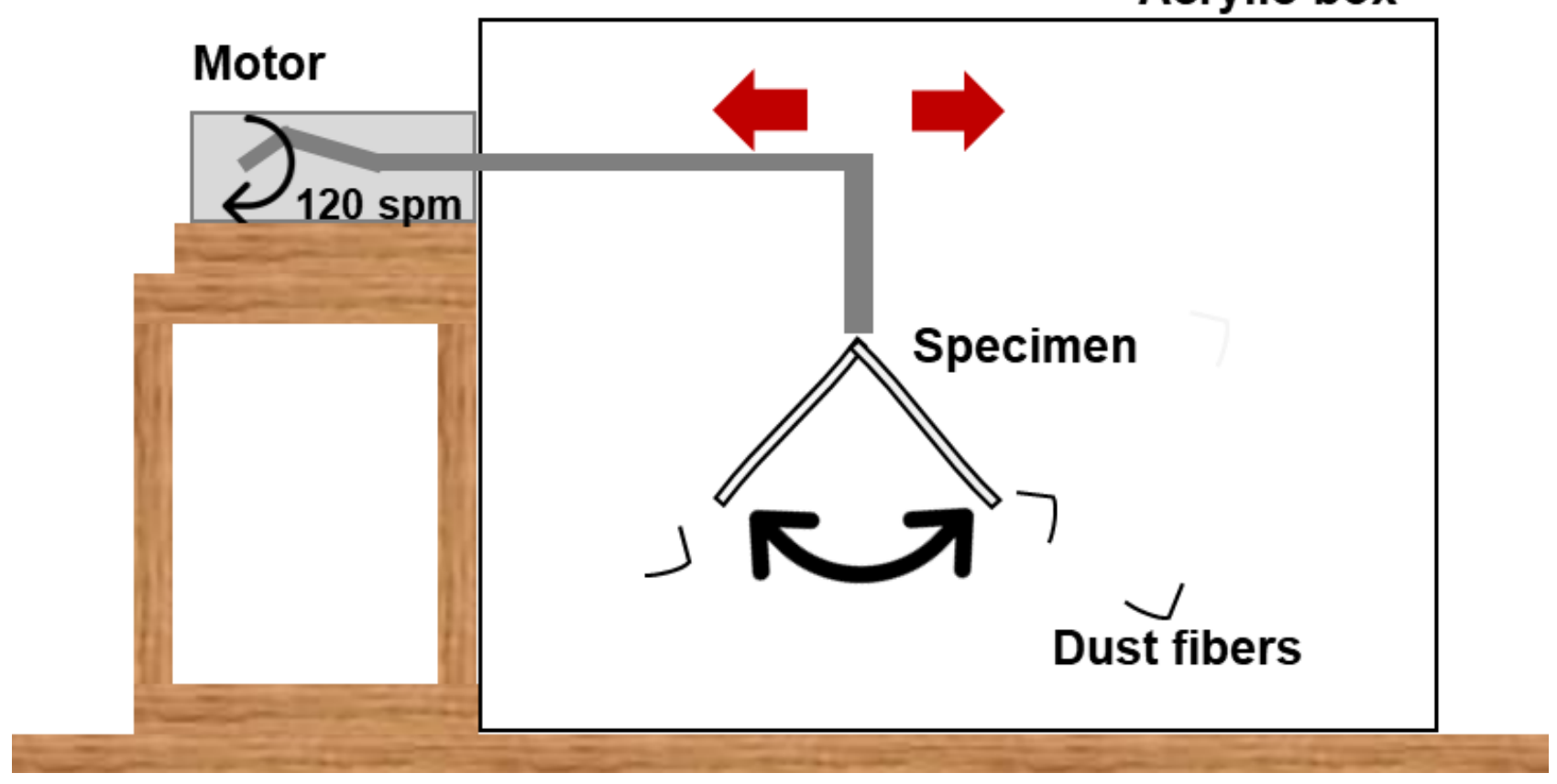

Figure 2

Airborne microfiber generation by TDA 
(a)

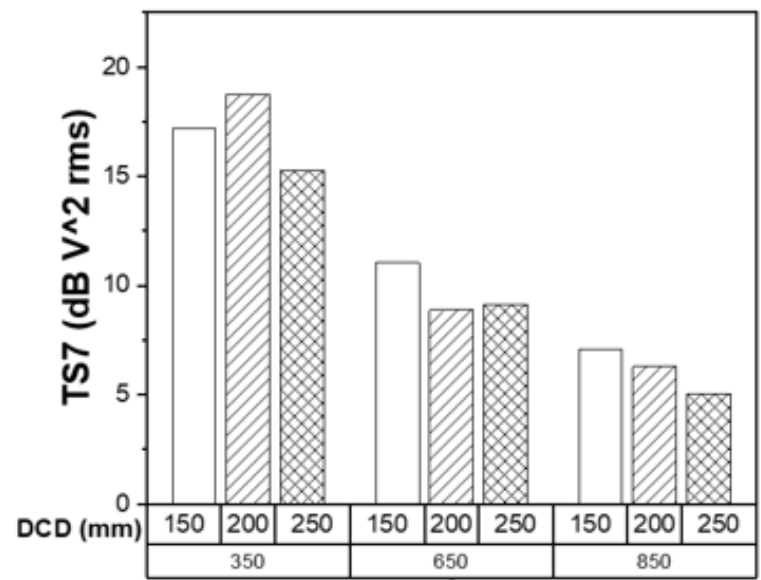

$\operatorname{Air}\left(\mathrm{m}^{3} / \mathrm{hr} / \mathrm{m}\right)$

(c)

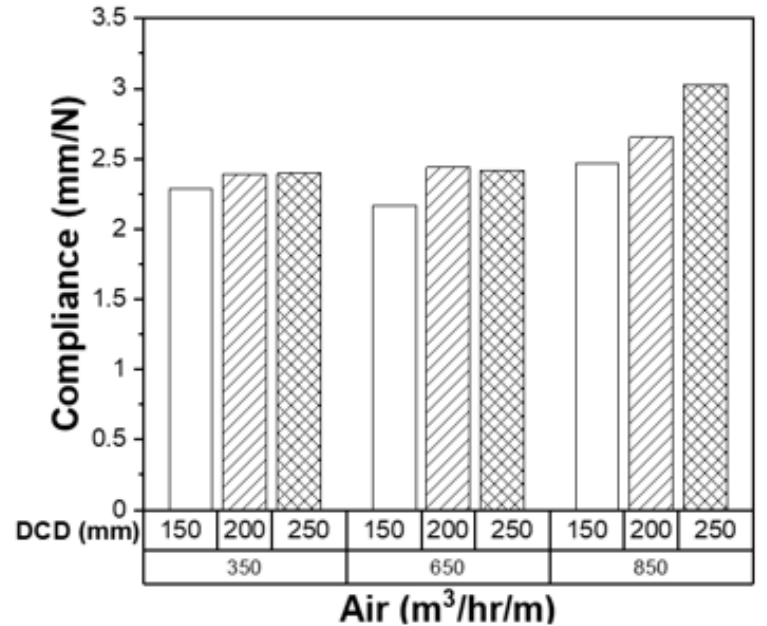

(b)

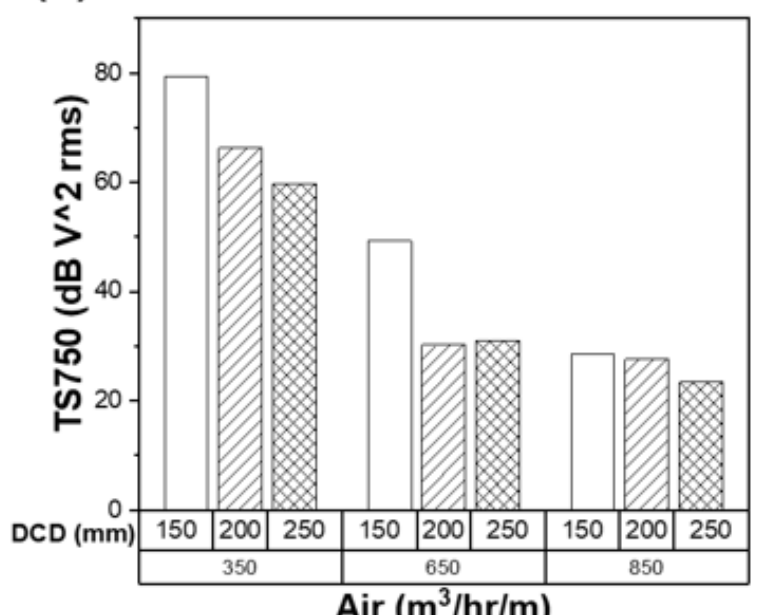

(d)

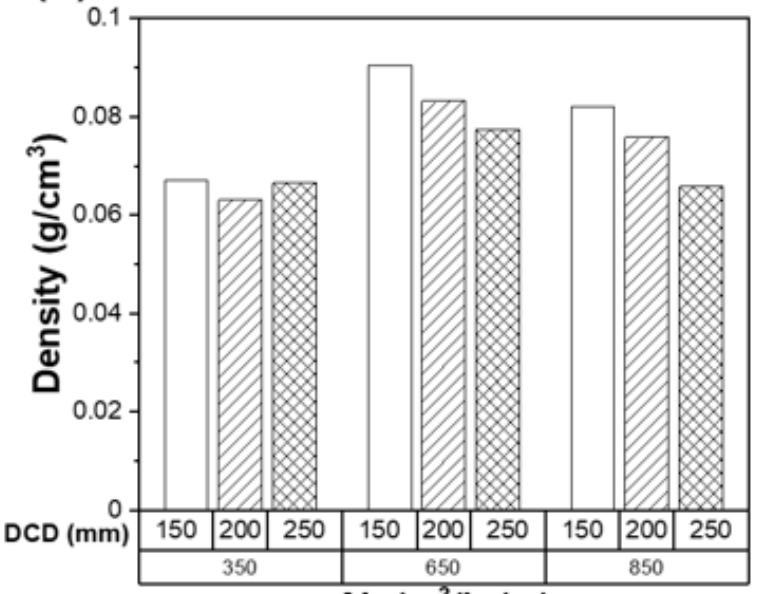

Air $\left(\mathrm{m}^{3} / \mathrm{hr} / \mathrm{m}\right)$

Figure 3

TSA results of meltblwon nonwovens depending on DCD. a: TS7 (the noise peak representing the softness of specimens), b: TS750 (the noise peak representing the roughness of specimens), c: compliance, and d: fabric density of meltblown nonwovens (all data represent the average values of the three repetitions; overall results are in the supplementary information). 


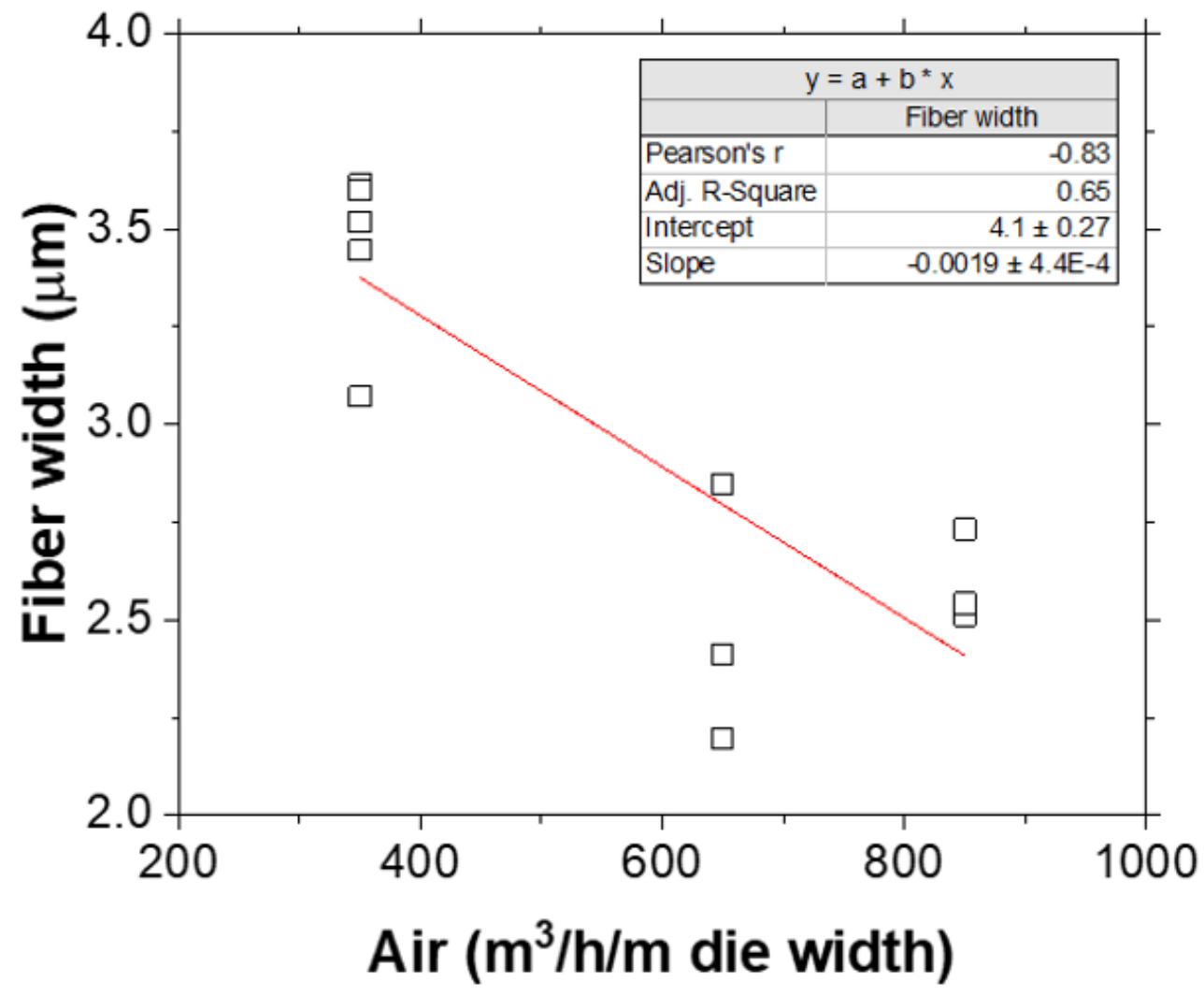

Figure 4

Fiber width versus airflow rate of meltblown nonwovens. The throughput was $15.5 \mathrm{~kg} / \mathrm{hr} / \mathrm{m}$.

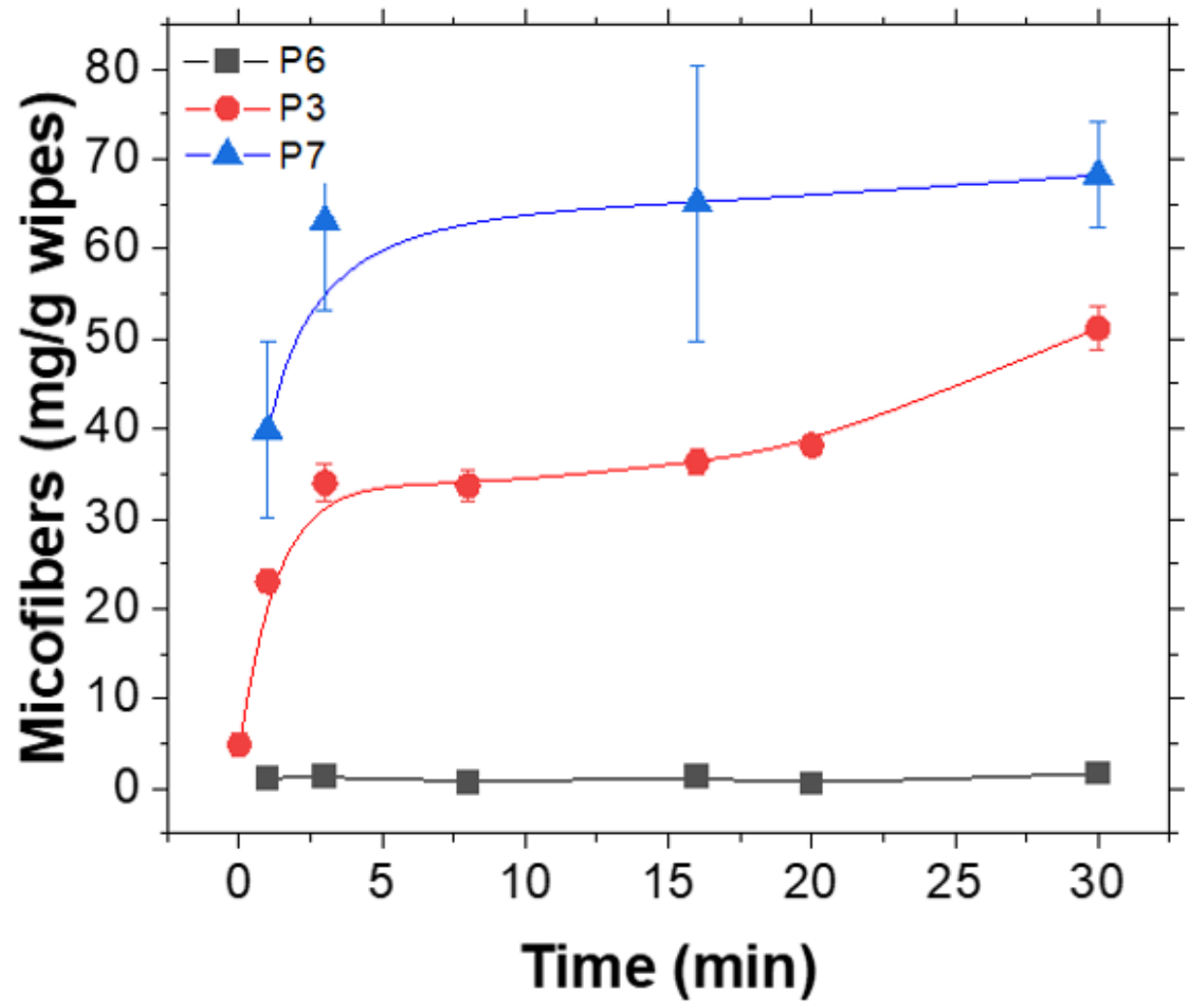


Figure 5

Waterborne microfiber generation of commercial nonwoven products depending on the duration of mechanical action. ( $\square$ : P6, $\mathrm{P} 3$, and $\mathbf{\Delta}: \mathrm{P} 7)$

\section{Figure 6}

Microfiber generation of nonwoven commercial products depending on (a) fiber type (Syn: synthetic fibers, RC: regenerated cellulosic fibers, NC: natural cellulosic fibers), (b) web formation (WL: wetlaid, SPS: spunbond-wood pulp-spunbond, MB:

meltblown, CF: CoForm, CM: carded and meltblown), and (c) bonding techniques (HE: hydroentangling, TB: thermal bonding). The values in the table are the average values of each category and the values in parentheses are the standard deviation from three repeated measurements.
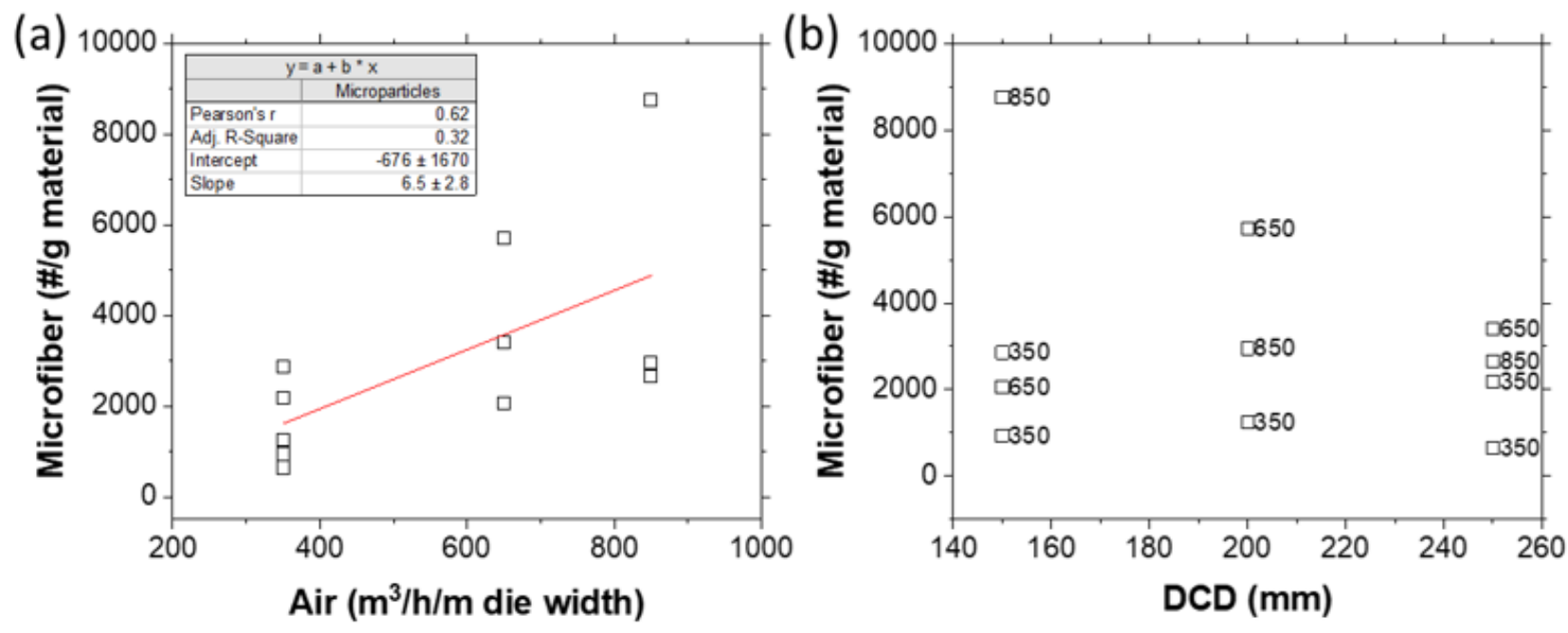

Figure 7

Microfiber number shed as measured by FQA versus (a) airflow rate and (b) DCD. The legend in the DCD graph is the airflow rate of the meltlblown nonwovens (m3/h/m die width). The throughput was $1.5 \mathrm{~kg} / \mathrm{hr} / \mathrm{m}$.

\section{Figure 8}

Microfiber generation of nonwoven commercial products by TDA depending on (a) fiber type (Syn: synthetic fibers, RC: regenerated cellulosic fibers, NC: natural cellulosic fibers), (b) web formation (WL: wetlaid, SPS: spunbond-wood pulp-spunbond, MB: meltblown, CF: CoForm, CM: carded and meltblown), and (c) bonding techniques (HE: hydroentangling, TB: thermal bonding). The values in the table are the average values of each category and the values in parentheses are the standard deviation from three repeated measurements.

\section{Figure 9}

Microfiber generation of meltblown nonwovens by TDA depending on basis weight. Airflow rate was $350 \mathrm{~m} 3 / \mathrm{h} / \mathrm{m}$ die width and the throughput was $15.5 \mathrm{~kg} / \mathrm{hr} / \mathrm{m}$.

\section{Supplementary Files}

This is a list of supplementary files associated with this preprint. Click to download. 
- SupplementaryMaterialOct19.docx

Page 23/23 